\title{
VOCAŢIA CULTURAL - FILANTROPICĂ A MONAHISMULUI CONTEMPORAN
}

\author{
Antim (Adrian) NAE*
}

\begin{abstract}
The cultural - philanthropic vocation of contemporary monasticism ${ }^{1}$. As we know, we live in a secularized and individualistic society affecting and influencing monastic life. The Church is called to be actively involved in solving the problems of individuals and society, especially at community level from the position and means that are specific to them under the ontological mission of serving the neighbor and based on the unique experience, which holds in this way. Monastic has gone through many attempts and crises in its history, through violently manifested, as those coming from pagan or of anti-religious ideologies or atheists such as communism. But there are also persecution or pressures not accompanied by violence in which faith and godliness, spiritual obedience, brotherly love of sacrifice, and the spirit of humility were weakened or reduced. Although over time, the monasteries have been an oasis of culture and philanthropy, by the existence of the printers, schools or hospitals, starting with the $19^{\text {th }}$ century, these activities were either taken over by church-owned organizations, or were laicized, or in more painful cases, they were banned. That is why in contemporary society, this need of practical models appeard, to fulfill the continuous prayer that the monastic owes to live his life, with cultural and philanthropic activities. The godly feeling of philanthropy and mercy is the fruit of a long and laborious Christian education, made with tact and with boundless love by the chosen ones. Today more than ever, the secularized world dominated by technologies, in which we live, needs humanization, mercy and love towards man and philanthropy.
\end{abstract}

"Ieromonah, PhD Student, Faculty of Orthodox Teology at „Ovidius” University, Constanţa, Romania.

${ }^{1}$ Studiu realizat sub coordonarea Pr. Prof. Univ. Dr. Nechita Runcan, care și-a exprimat acordul pentru publicare. 
Keywords: culture, philanthropy, monastic, secularization.

Încă de la începuturile sale, monahismul a căutat desăvârşirea duhovnicească, zidirea „omului celui nou” (Efes. 2, 5), îndumnezeirea, dorind să pună bazele unei societăţi lipsită de imoralitate şi nedreptate, $o$ adevărată , ,cetate a lui Dumnezeu”, unde fiecare „cetăţean” să se vindece de păcat şi patimă ${ }^{2}$. Astfel, mănăstirea - în sensul larg al cuvântului devine şcoală unde se învaţă lupta împotriva patimilor şi păcatelor, dar şi spital în care să se vindece rănile sufleteşti şi trupeşti pricinuite de acestea.

Hristos, „Doctorul sufletelor şi al trupurilor noastre”, a pus la dispoziţia tuturor creştinilor harul Său vindecător, prin Sfintele Taine ale Bisericii, atâta vreme cât puterea şi sinceritatea credinţei rămân ferme în ființa umană, căci Hristos dăruieşte tuturor bolnavilor vindecarea sufletească şi trupească, iertarea păcatelor şi tămăduirea de orice boală (Mc. 6, 13; Iac. 5, 14-15)

Alături de harul sfințitor, de cuvântul inspirat şi de rugăciunea înaripată de credinţă, alături de mijloacele dumnezeieşti de chemare la viaţa cea nouă în Hristos, de primenire şi de continua zidire duhovnicească, Biserica a folosit într-o largă măsură şi mijloacele omeneşti de ajutorare morală şi materială a celor cuprinse şi în aria lucrării sale mântuitoare. Biserica însăşi a trebuit, potrivit naturii ei, să se organizeze în chip de societate religioasă, folosind mijloacele obişnuite ale organizării sociale, între care şi pe cele materiale-economice. De altfel, rostul sau misiunea Bisericii a reclamat şi a impus folosirea acestora, întrucât fără ele nu se poate asigura nici viaţa, nici lucrarea Bisericii în lume $\mathrm{s}^{4}$.

Aşadar, scopul acestui articol este de a arăta dragostea lucrătoare şi comuniunea specifică Ortodoxiei, atât în ceea ce priveşte filantropia, cât, mai ales, participarea activă în domeniul cultural, pe care mănăstirile au avut-o în viaţa comunităţilor din care au făcut parte. Căci dragostea,

2 Nicolae CoRnEAnu, „Cu privire la originea monahismului creştin”, în Mitropolia Banatului, Anul V, 1955, Nr. 4-6, p. 90.

3 Jean-Claude LARCHET, Terapeutica bolilor spirituale, trad. Marinela Bojin, Bucureşti, Edit. Sophia, 2001, p. 8.

4 Varlaam MerTiCARIU, „Dimensiunea vindecătoare a monahismului”, în Teologie şi

Viaţă, Anul XIII, Nr. 7-12, iulie-decembrie, 2004, p. 129. 
comuniunea şi slujirea liturgică şi socială sunt temelia învăţăturii ortodoxe. Cea mai frumoasă definiţie a ceea ce am spus până acum ne-o dă părintele Isidor Todoran, care spune: „,...dragostea lucrătoare întemeiază comuniunea omului credincios cu Dumnezeu, iar dacă această comuniune se sfărâmă, din pricina omului, numai dragostea poate să o restabilească, coborându-se, slujind...aşadar, esenţial, dragostea e darul coborârii mântuitoare a lui Dumnezeu Însuşi în lume, ca har" "5.

Toate acestea ne arată că Biserica, prin extensia ei, mănăstirea, este deschisă umanităţii într-un mod adecvat, devenind astfel Biserică responsabilă $\breve{a}^{6}$, având un caracter de servire a comunităţii, după cum arată părintele Dumitru Stăniloae: „Servirea porneşte dintr-un sentiment al egalităţii şi al comunităţii naturale a oamenilor şi urmăreşte refacerea lor"7.

Două au fost preocupările majore ale călugărilor români dintotdeauna: rugăciunea şi munca. Pe lângă obligaţia participării tuturor la slujbe, fiecare din ei avea şi câte o responsabilitate specială, numită ,ascultare”. Cei cu învăţătură erau hirotoniţi şi încredinţaţi cu oficierea slujbelor amintite. Alţii se ocupau cu copierea de manuscrise necesare pentru slujbe sau pentru lectura obştei. În secolele XVI-XIX apar călugării-tipografi. În mănăstirile cu şcoli, călugării cu învăţătură funcţionau ca dascăli. Ceilalţi erau încredinţaţi cu diverse munci „manuale”: la câmp, la creşterea animalelor, în apicultură, viticultură, pomicultură, piscicultură etc. În aproape toate mănăstirile existau ateliere în care se lucrau cele trebuitoare vieţuitorilor (veşminte liturgice, postavuri, rase, potcapuri, încălţăminte, lumânări, cruciuliţe, icoane ş.a.). În mănăstirile de călugăriţe existau ateliere de ţesut şi de brodat. Cu alte cuvinte, fiecare vieţuitor trebuia să aibă o ocupaţie, rânduială care se respectă în mănăstirile româneşti până astăzi.

Mănăstirile au îndeplinit în viaţa poporului român, înainte de toate, un rol duhovnicesc. Ele puteau fi cercetate de orice credincios care dorea

5 Isidor Todoran, „Eros şi agape”, în Studii Teologice, Anul VIII (1956), Nr. 3-4, p. 143.

${ }^{6}$ Athanase NegoIŢĂ, „Ideile umanitare ale creştinismului”, în Studii Teologice, Anul III (1951), Nr. 5-6, p. 340.

${ }^{7}$ Dumitru StĂniloAe, ,Servire şi proexistenţă”, în Glasul Bisericii, Anul XXII (1963),

Nr. 11-12, p. 1020. 
să asiste la slujbe, să se spovedească şi să se împărtăşească, să ceară îndrumări de viaţă de la duhovnici cu renume.

Apoi, ele au avut şi un rol însemnat în istoria culturii româneşti; aici s-au scris şi numeroase lucrări originale, fie teologice, fie istorice. Între autorii de lucrări originale consemnăm pe Sfântul Nicodim de la Tismana cu Tetraevangheliarul (1404-1405) şi cele două scrisori adresate patriarhului de Târnovo, Eftimie, şi pe Filotei, monahul de la Cozia, cu aşa-numitele Pripeale, scurte texte imnografice pe autorii anonimi ai unor lucrări istorice, precum Pomelnicul de la Bistriţa, Letopiseţul de la Putna ş.a. În secolul al XVI-lea, episcopii Macarie al Romanului şi Eftimie al Rădăuţilor, împreună cu călugărul Azarie, au fost autorii unor Cronici; Isaia, viitorul episcop de Rădăuţi, a realizat la Slatina prima colecţie de cronici în Moldova ${ }^{8}$.

De regulă, egumenii şi alţi călugări cărturari au fost promovaţi în scaune mitropolitane sau episcopale. Mulţi alţi călugări cu învăţătură şiau dus însă viaţa potrivit pravilei călugăreşti, numai în zidurile mănăstirii lor, cum au fost: Mihail Moxa (care a tradus Pravila de la Govora din 1640), Meletie Macedoneanul şi Ştefan din Ohrida, toţi la Govora, Silvestru, traducătorul Noului Testament de la Alba Iulia din 1648, Mardarie Cozianul, autorul unui Lexicon slavo-român rămas în manuscris (1649), Vartolomeu Măzăreanu, Lavrentie şi Rafail de la Hurezi, Naum Râmniceanu, Dionisie Eclesiarhul, la care se adaugă şi numeroşi alţi copişti de manuscrise ${ }^{9}$.

Pe lângă multe mănăstiri funcţionau şcoli, care răspândeau ştiinţa de carte cu caracter bisericesc şi laic. În aceste şcoli se predau cunoştinţele trebuitoare pentru cei care urmau să devină preoţi, precum şi dieci, logofeţi şi caligrafi în cancelaria domnească. Astfel de şcoli au funcţionat la mănăstirile Vodiţa, Tismana etc. La Putna, de pildă, funcţiona, în secolul al XVI-lea, o şcoală elementară, dar şi una medie, în care se predau gramatica, retorica, logica, muzica, limbile: greacă, slavonă şi română. La această şcoală au funcţionat ca dascăli: călugărul Eustatie, „ritor, protopsalt şi domesticos” de muzică bisericească, autorul unor lucrări muzicale (1511), ieromanahul

${ }^{8}$ Mircea Păcurariu, Istoria Bisericii Ortodoxe Române, Vol. I, Iaşi, Edit. Trinitas, 2004, p. 212.

${ }^{9}$ Ibidem, p. 242. 
Antonie (1545), apoi „ritorul şi scolastiul” Lucaci, care a întocmit o Pravilă în româneşte şi slavoneşte. Un renumit dascăl, Dositei, a activat vreo patru decenii la schitul lui Zosima pe Valea Secului, situat în apropiere de viitoarea mănăstire Secu.

Şcoli speciale pentru pregătirea viitorilor preoţi au funcţionat la mănăstirea Putna (între anii 1774-1782), apoi la mănăstirea Sfântul Ilie de lângă Suceava, la mănastirea Obedeanu din Craiova (1775), la Antim din Bucureşti (1797-1874), la mănastirea Glavacioc. Primul seminar propriu-zis din Moldova a luat fiinţă în incinta mănăstirii Socola de lângă Iaşi (1803). În secolele XVIII-XIX se cunosc o serie de şcoli în diferite mănăstiri, pentru pregătirea călugărilor, a călugăriţelor sau a copiilor din satele din jur.

Marile mănăstiri posedau biblioteci cu numeroase manuscrise şi tipărituri: Neamţ, Putna, Mărgineni, Dragomirna, Secu, Cernica, Căldăruşani etc. În Transilvania, Banat şi Maramureş s-au copiat, de asemenea, o serie de manuscrise cu caracter liturgic, istoric şi teologic. În multe din ele existau şcoli pentru pregătirea călugărilor şi, mai ales, a copiilor din satele învecinate ${ }^{10}$.

Mănăstirile româneşti au îndeplinit de asemenea şi un însemnat rol social-umanitar.

Opera de asistenţă socială organizată de mănăstirile româneşti, deşi puţin cercetată, merită să ne reţină atenţia. La Putna, de pildă, s-a făcut o copie după un tratat de medicină scris în limba latină, cu o însemnare din 1536, care vorbea de arderea bolniţei, ceea ce duce la presupunerea că aceasta exista mai demult, poate chiar în timpul domnitorului Ştefan cel Mare.

Mănăstirea Argeş avea în 1524 două aşezăminte de asistenţă socială: o bolniţă şi un „xenodochion”, adică o casă pentru îngrijirea gratuită a călătorilor şi a străinilor - de regulă trei zile - amândouă situate în satul Flămânzeşti, în apropierea mănăstirii. În acelaşi secol s-au ridicat bolniţe noi la Bistriţa, în Oltenia (cca. 1520-1521), la Cozia (1542-1543) şi în alte părţi, în care primeau îngrijire gratuită nu numai călugării bătrâni şi bolnavi, ci şi unii credincioşi. La începutul secolului al XVII-lea s-a ridicat bolniţa lui Anastasie Crimca de la Dragomirna. La sfârşitul

${ }^{10}$ Gheorghe BARIȚ, Istoria Transilvaniei, Vol. I, Sibiu, f. edit., 1889, p. 172. 
secolului, s-au ridicat bolniţe la mănăstirile Sadova (1692-1693), Hurezi $(1696-1699)^{11}$.

Prin anii 1701-1702, spătarul Mihai Cantacuzino a ctitorit mănăstirea Colţea din Bucureşti, având şi „o bolniţă şi o casă de străini, spre odihna şi mângâierea întru Hristos a fraţilor noştri săraci care pătimesc de boale"12, cu 12 paturi pentru bărbaţi şi 12 pentru femei, întreţinuţi gratuit. Era primul „spital” din Bucureşti, situat pe locul celui modern de azi, întreţinut din veniturile mănăstirii, deci o bolniţă mănăstirească unde aveau acces şi credincioşii din jur ${ }^{13}$.

În testamentul mitropolitului Antim Ivireanul, mănăstirea ,Toţi Sfinţii” din Bucureşti (Antim), ctitoria sa, a lăsat o serie de dispoziţii prin care se fixau anual anumite sume din veniturile ei pentru opere umanitare, precum: înmormântarea celor săraci, înzestrarea unei fete pentru căsătorie, îmbrăcăminte pentru trei săraci şi trei fete în fiecare an, întreţinerea gratuită pe trei zile în mănăstire a celor străini, întreţinerea la şcoală a trei copii săraci, anual, ajutoare săptămânale pentru cei săraci şi cei aflaţi în închisori.

Dimitrie Cantemir (1673-1723), în lucrarea sa Descrierea Moldovei, sublinia faptul că în mănăstirile moldovene era primit orice călător, fie ortodox, fie armean, turc sau evreu, având întreţinere gratuită chiar şi timp mai îndelungat, dacă era nevoie ${ }^{14}$.

În secolul al XVIII-lea au luat fiinţă noi ,,spitale mănăstireşti”: la Sfântul Pantelimon, lângă Bucureşti, ctitoria lui Grigorie II Ghica, cu secţie de boli cronice, de ciumă şi febră tifoidă; la mănăstirea Sfântul Spiridon din Iaşi (1757-1759), ,pentru căutarea şi buna odihnă a celor mulţi bolnavi şi neputincioşi şi săraci, ce se află din pământeni şi străini"15; ,spitalul” de pe lângă mănăstirea Sfântul Prooroc Samuil din Focşani; ,spitalul” de pe lângă mănăstirea Precista Mare din Roman

${ }^{11}$ Ligia LIVADĂ-CADESCHI, Sărăcie și asistență socială în spațiul românesc (sec. XVIIIXX), București, Edit. Colegiul Noua Europă, 2002, p. 15.

${ }^{12}$ Idem, De la milă la filantropie. Instituții de asistare a săracilor din Țara Românească și Moldova în secolul al XVIII-lea, București, Edit. Nemira, 2001, p. 32.

${ }^{13}$ Ibidem, p. 35.

14 Valentina şi Andrei EşAnu, „Studiu introductiv” la Descrierea Moldovei, Vol. II, Bucureşti, I.C.R., 2007, p. 5-7.

${ }^{15}$ Ligia LIVADĂ-CADESCHI, De la milă la filantropie. Instituții de asistare a săracilor din Țara Românească şi Moldova în secolul al XVIII-lea, p. 44. 
(1789), înfiinţat de egumenul Gherasim Putneanul, acţiune desăvârşită de urmaşul său Vartolomeu Putneanul, care a creat şi o „spiţerie” $(\text { farmacie })^{16}$.

Din toate aceste ,spitale mănăstireşti” s-au dezvoltat actualele spitale din oraşele respective. Bolnavii se bucurau de întreţinere şi asistenţă medicală gratuită, după posibilităţile şi cunoştinţele de atunci, iar personalul medical era plătit din veniturile acelor mănăstiri. Pe lângă spitalele din mediul urban şi-au continuat existenţa şi vechile bolniţe, ridicându-se şi altele. De pildă, stareţul Paisie a reorganizat pe cele de la Dragomirna şi Secu, iar la Neamţ a făcut una aparte, pentru bolnavii de nervi ${ }^{17}$.

În anii 1874-1852 stareţul Neonil Buzilă de la Neamţ a ridicat actualul spital din Târgu Neamţ. Se cunosc călugări care au alcătuit lucrări de medicină empirică, cum a fost Nicanor bolnicerul de la Cernica, cu o Carte dohtoricească, rămasă în manuscris (1854) şi Dionisie arhimandritul, care a tradus din greceşte Medicina practică $(2$ vol., tipărită în 1848). Activitatea spitalelor de pe lângă mănăstiri a încetat după 1863, anul secularizării averilor mănăstireşti, continuânduşi existenţa numai bolniţele. Prin aceasta se poate observa că mănăstirile româneşti au desfăşurat o însemnată acţiune filantropică ${ }^{18}$.

Oamenii şi mediul social aşteaptă să vadă în cei care fac parte din Biserică, mai ales din mediul monahal, un exemplu, nu un prilej de poticneală şi de sminteală. Lor le sunt analizate toate detaliile vieții, şi de multe ori sunt supuşi unor judecăţi sociale mai aspre decât restul celor care nu practică în mod regulat nici un fel de credinţă sau religie şi nici nu frecventează biserica. Păcatele mici ale monahilor sunt echivalate cu păcatele mari ale mirenilor. Sfântul Simeon, într-un imn al său, exprimă destul de sugestiv: „Cine nu mă va plânge, cine nu mă va jeli cu putere? Că am fugit de lume şi de cele din lume, dar cu simţirea nu m-am depărtat de lume? Am îmbrăcat schima cerească şi iubesc pe cele din lume, slava, bogăţia, plăcerile şi desfătările? ${ }^{19}$ ". Cuvintele Sfântului Simeon Noul

${ }^{16}$ Ibidem, p. 45.

${ }^{17}$ Idem, Sărăcie și asistență socială în spațiul românesc (sec. XVIII-XX), p. 17.

18 Dario Roccanello, Rugăciunea lui Iisus în scrierile stareţului Vasile de la Poiana Mărului, trad. Maria-Cornelia Oros, Sibiu, Edit. Deisis, 1996, p. 29.

${ }^{19}$ Sfântul Simeon Noul TeOlog, Imne, Epistole şi Capitole, trad. Ioan Ică Jr., Sibiu, Edit.

Deisis, 2001, p. 245. 
Teolog sunt o reamintire a datoriilor celor care urmează această viaţă. Nu ne face vrednici schima şi îmbrăcămintea, nu ne mântuieşte şederea în chilie, ci ceea ce ne mântuiește este smerenia, pocăinţa, curăţirea inimii şi rugăcinea neîncetată.

Secularizarea nu este legată de anumite părţi ascunse ale vieţii bisericeşti care au fost exprimate într-un anumit timp, ci de rămânerea omului la limitele cele mai de jos ale vieţii duhovniceşti, fără să aştepte ceva mai profund şi mai înalt. Acest lucru a fost observat în toate epocile, chiar şi în perioada apostolică. Însă într-un mare grad s-a exprimat în perioada de după persecuţii, când creştinismul a dobândit libertatea. Trăirea prin arătarea reală a Împărăţiei lui Dumnezeu a fost identificată cu realitatea lumească, pământească, iar pocăinţa a fost înlocuită cu dominaţia lumească interpretată ca binecuvântare a lui Dumnezeu. Aşadar, a intrat în sânul Bisericii denaturarea vieţii profetice, apostolice şi martirice. Denumim această denaturare secularizare. Oportunităţile, conformarea cu lumea şi mentalitatea ei, au creat mari probleme. Într-o astfel de societate secularizată s-a dezvoltat puternic monahismul, ca încercare de trăire a poruncilor lui Hristos şi dobândirea scopului pentru care a fost creat omul.

Omul contemporan are nevoie de model, de concret. Acest model poate să-l găsească în monahul îmbunătăţit. Referitor la aceasta, părintele Dumitru Stăniloae scrie: „În România nu există pustiuri, ci numai mănăstiri. Dar cu cât un călugăr dintr-o mănăstire este mai duhovnicesc, adică se roagă mai mult, cu atât el este mai căutat de către popor. Un asemenea călugăr îşi împlineşte nu numai propria nevoie de rugăciune, dar şi setea spirituală a celor ce-l caută" ${ }^{20}$.

După Sfầntul Simeon Noul Teolog, monah nu este acela care doar locuieşte în mănăstire şi este îmbrăcat în schima de monah, ci e acela care permanent se împărtăşeşte de Dumnezeu. „Monah este cel care nu se amestecă cu lumea, ci vorbeşte pururea cu Dumnezeu"21.

Monahul trebuie să considere că mănăstirea este o insulă în mijlocul mării şi s-o întâmpine ca pe un ţinut neumblat, eventual să existe o mare prăpastie împrejurul mănăstirii, ca să nu treacă nici cei din lume

${ }^{20}$ Dumitru StăniloAe, Rugăciunea lui Iisus şi experienţa Duhului Sfânt, Sibiu, Edit. Deisis, 2003, p. 39.

${ }^{21}$ Idem, Studii de Teolgie Dogmatică, Craiova, Edit. Mitropoliei Olteniei, 1990, p. 369. 
spre mănăstire, nici cei din insulă să treacă spre cei din lume şi să privească împătimiţi spre ei, ba nici amintirea lor să nu se întoarcă în inima şi-n mintea lor $^{22}$. Chiar după ieşirea sa din lumea păcatului şi după ce a realizat deplina maturitate duhovnicească, un monah nu trebuie să facă mai mult decât să fie gata a da şi a jertfi fără să-şi părăsească postul de santinelă duhovnicească. Dacă este conştient de plinătatea sa în Hristos, un monah poate să tragă lumea la el şi să ridice pe oameni la nivelul său, fără să se clintească din locul retragerii sale.

Când vorbim despre secularizarea monahismului, vom puncta următoarele idei: în primul rând, putem vorbi despre pierderea duhului pocăinţei, care este foarte strâns legată de curăţia inimii, ca premergătoare iluminării minţii. Pocăinţa nu este un regret de provenienţă omenească, ci lucrarea luminii dumnezeieşti, a harului dumnezeiesc. „Când vine în inima omului harul dumnezeiesc, luminează lumea lăuntrică şi este descoperită boala lăuntrică, de unde încep să răsară râuri de lacrimi"23. Astfel, secularizarea se identifică cu pierderea metodei isihasteevanghelice, care este pocăinţa unită cu plânsul.

De asemenea, duhul lumesc se manifestă în unele mănăstiri prin faptul că unii monahi nu acceptă să trăiască în ascultare şi supunere, aspirând mereu spre superioritate, o caracteristică a acestui veac care aleargă după putere şi stăpânire. Dintre cele trei făgăduinţe monahale, ascultarea necondiţionată s-a dovedit cea mai grea, din două motive cu totul opuse: infirmitatea firii şi personalitatea ei. Disciplina ascultării însă e generală, pentru că ea ridică firea din infirmitate şi scoate mândria din personalitate. De pildă, mulţi vin la mănăstire cu o părere bună despre ei înşişi, părere pe care nemărturisit şi-o păstrează şi în mănăstire. Părerea sau iubirea de sine e o formă subţire a mândriei.

Toate aceste piedici individuale duc la dezbinarea sau chiar destrămarea unei obşti monahale. Unitatea unei mănăstiri depinde de starea sufletească a fiecărui membru în parte. Referitor la acest lucru, părintele Zaharia Zaharou spune că: „Unitatea depinde de gândurile pe care le avem atunci când suntem la noi în chilie. Dacă avem un gând rău

${ }^{22}$ Imnul 41, apud Ibidem, p. 594-595.

${ }^{23}$ Ierotei Vlahos, Monahismul ortodox ca viaţă profetică, apostolică şi martirică, trad.

Monahul Calist, Craiova, Edit. Mitropoliei Olteniei, 2005, p. 277. 
asupra fratelui, un gând de judecată sau orice alt gând negativ, gândul acesta este o crăpătură în zidul mănăstirii" 24 .

O altă manifestare a duhului lumesc este preocuparea excesivă de a construi ziduri, în detrimentul zidirii duhovniceşti. Iată ce spunea părintele Petroniu Tănase: „S-au construit mănăstirile, Dumnezeu le-a pregătit, pentru ca să nu mai aibă călugării de lucrat la ele, ci să se ocupe de adâncirea vieţii duhovniceşti. Au acum Filocaliile, care mai înainte nu erau nici la facultate, dar nici la mănăstire nu se ştia de ele. Acum avem la îndemână un noian de cărţi. Dacă oamenii sunt îndrumaţi să se hrănească din hrana aceasta a Sfinţilor Părinţi, rodul vine îndată"25.

Monahismul nu poate fi înţeles deplin prin simpla raţiune, iar dacă omul nu se opreşte cuvios în faţa tainei, riscă să ajungă să acuze ceea ce, de fapt, nu cunoaşte decât parţial. Poate acesta este unul din motivele pentru care lumea contemporană priveşte deseori cu scepticism monahismul sau îl interpretează în funcţie de propriile mentalităţi, ajungând la înţelegerea greşită a acestui mod de a sluji lui Dumnezeu ${ }^{26}$.

În concluzie, remarcăm că slujirea filantropică şi culturală a Bisericii a constituit o prioritate, fiind prezentă în toate timpurile şi locurile, având un caracter dinamic, mereu orientată spre necesităţile fiilor ei duhovniceşti, atât în ceea ce priveşte trupul, dar şi sufletul şi mintea.

\section{Referinţe bibliografice:}

1. BARIT, Gheorghe, Istoria Transilvaniei, Vol. I, Sibiu, f. edit., 1889;

2. CoRnEAnU, Nicolae, „Cu privire la originea monahismului creştin”, în Mitropolia Banatului, Anul V, 1955, Nr. 4-6;

3. „Dialog cu Părintele Petroniu Tănase” în rev. Vestitorul Ortodoxiei, IV (1993, 1 nov.), p. 3;

4. EşANU, Valentina şi Andrei, „Studiu introductiv” la Descrierea Moldovei, Vol. II, Bucureşti, I.C.R., 2007;

5. Giosanu, Cosma, Răstignirea monahismului românesc la mijlocul secolului al XX-lea, Iaşi, Edit. Sfântul Mina, 2009;

24 Zaharia Zaharou, Merinde pentru monahi, Putna, Edit. Nicodim Caligraful, 2012, p. 77.

25 „Dialog cu Părintele Petroniu Tănase” în rev. Vestitorul Ortodoxiei, IV (1993, 1 nov.), p. 3.

${ }^{26}$ Cosma Giosanu, Răstignirea monahismului românesc la mijlocul secolului al XX-lea, Iaşi, Edit. Sfântul Mina, 2009, p. 240. 
6. LARCHET, Jean-Claude, Terapeutica bolilor spirituale, trad. Marinela Bojin, Bucureşti, Edit. Sophia, 2001;

7. LIVADĂ-CADESCHI, Ligia, Sărăcie și asistență socială în spațiul românesc (sec. XVIII-XX), București, Edit. Colegiul Noua Europă, 2002;

8. LIVADĂ-CADESCHI, Ligia, De la milă la filantropie. Instituţii de asistare a săracilor din Țara Românească și Moldova în secolul al XVIII-lea, București, Edit. Nemira, 2001;

9. MERTICARIU, Varlaam, „Dimensiunea vindecătoare a monahismului”, în Teologie şi Viaţă, Anul XIII, Nr. 7-12, iulie-decembrie, 2004;

10. NegOIȚĂ, Athanase, „Ideile umanitare ale creştinismului”, în Studii Teologice, Anul III (1951), Nr. 5-6;

11. PĂCURARIU, Mircea, Istoria Bisericii Ortodoxe Române, Vol. I, Iaşi, Edit. Trinitas, 2004;

12. RocCANEllo, Dario, Rugăciunea lui Iisus în scrierile stareţului Vasile de la Poiana Mărului, trad. Maria-Cornelia Oros, Sibiu, Edit. Deisis, 1996;

13. Sfântul SimeOn Noul TeOLOG, Imne, Epistole şi Capitole, trad. Ioan Ică Jr., Sibiu, Edit. Deisis, 2001;

14. STĂNILOAE, Dumitru, ,Servire şi proexistenţă”, în Glasul Bisericii, Anul XXII (1963), Nr. 11-12;

15. StăniloAe, Dumitru, Studii de Teolgie Dogmaitcă, Craiova, Edit. Mitropoliei Olteniei, 1990;

16. StĂNILOAE, Dumitru, Rugăciunea lui Iisus şi experienţa Duhului Sfânt, Sibiu, Edit. Deisis, 2003;

17. TODORAN, Isidor, „Eros şi agape”, în Studii Teologice, Anul VIII (1956), Nr. 3-4;

18. Vlahos, Ierotei, Monahismul ortodox ca viaţă profetică, apostolică şi martirică, trad. Monahul Calist, Craiova, Edit. Mitropoliei Olteniei, 2005;

19. Zaharou, Zaharia, Merinde pentru monahi, Putna, Edit. Nicodim Caligraful, 2012. 